patients who had used only two topical preparations recalled an initial response and then a subsequent deterioration with generalisation of itch when using this preparation. This is circumstantial evidence that the continued use of Tri-Adcortyl cream may induce the sensitivity. Provost and Jillson reported two patients, sensitive to ethylenediamine, who developed a widespread dermatitis after systemically administered aminophylline. Exfoliative dermatitis was the outcome in another patient described by Petrozzi and Shore. ${ }^{4}$ Several antihistamines are related to ethylenediamine and the use of these should be restricted. In particular, Fisher ${ }^{1}$ suggested that tripelennamine hydrochloride tablets or topical ophthalmic preparations with antazoline phosphate should be avoided. Hydroxyzine hydrochloride and mepyramine maleate are also considered to be potential hazards. Calnan ${ }^{5}$ has reported one patient with allergy to ethylenediamine, piperazine, and hydroxyzine.

Many topical preparations contain potential sensitising agents. If manufacturers listed the composition of their products more completely, the investigation of unresponsive dermatoses would be simplified. The sensitivity to ethylenediamine has been described because of its importance.

${ }^{1}$ Fisher, A A, Contact Dermatitis, 2nd ed. Philadelphia, Lea and Febiger, 1973.

2 Epstein, E, and Maibach, H I, Archives of Dermatology, 1968, 98, 476.

3 Provost, T T, and Jillson, O F, Archives of Dermatology, 1967, 96, 231.

${ }^{4}$ Petrozzi, J W, and Shore, R N, Archives of Dermatology, 1976, 112, 525.

${ }^{5}$ Calnan, C D, Contact Dermatitis, 1975, 1, 126.

(Accepted 26 October 1977)

Department of Dermatology, Aberdeen Royal Infirmary, Aberdeen AB9 2ZB

MARION I WHITE, MB, MRCP, senior registrar

W STEWART DOUGLAS, MB, MRCP, senior registrar (present appointment: consultant dermatologist, Monklands District General Hospital, Airdrie ML 6 0JS)

ROBERT A MAIN, MB, FRCP, consultant dermatologist

\section{Thalassaemia minor, iron overload, and hepatoma}

Although haemochromatosis has been described in association with several chronic haemolytic anaemias, such patients have usually received many blood transfusions. Iron overload has been rarely reported in thalassaemia minor in the absence of exogenous iron. ${ }^{1}$ Hepatocellular carcinoma occurs in some $8-22 \%$ of patients with primary haemochromatosis ${ }^{2}$ but is rare in secondary iron overload. This report describes a patient with thalassaemia minor who developed iron overload and died of a hepatoma.

\section{Case report}

In January 1975 a 74 -year-old retired docker was admitted with an acute exacerbation of his longstanding chronic bronchitis. Eighteen years previously he had had a Polya gastrectomy for peptic ulcer. At no time had he received oral iron or blood transfusion and he was not a heavy drinker. A distant ancestor was French. He was grey, pale, and weighed $46 \mathrm{~kg}$. A smooth non-tender liver was palpable two fingers below the costal margin. The haemoglobin $(\mathrm{Hb})$ concentration was $6 \mathrm{~g} / \mathrm{dl}$, mean corpuscular volume (MCV) $87 \mathrm{fl}\left(87 \mu \mathrm{m}^{3}\right)$, and mean corpuscular haemoglobin $(\mathrm{MCH}) 26 \mathrm{pg}$. The blood film showed moderate anisocytosis, poikilocytosis, and hypochromia with many schistocytes and target cells. $\mathrm{HbA}_{2}$ was $4 \%$ and $\mathrm{HbF}$ $4.2 \%$. Serum folate was $0.6 \mu \mathrm{g} / 1(0.6 \mathrm{ng} / \mathrm{ml})$ and serum vitamin $B_{12} 110 \mathrm{ng} / 1$
$(110 \mathrm{pg} / \mathrm{ml})$. The bone marrow showed megaloblastic erythropoiesis. The anaemia was attributed to nutritional deficiency related to partial gastrectomy and thalassaemia minor. The serum iron concentration was $37 \mu \mathrm{mol} / \mathrm{l}$ $(207 \mu \mathrm{g} / 100 \mathrm{ml})$ and total iron binding capacity $40 \mu \mathrm{mol} / 1(225 \mu \mathrm{g} / 100 \mathrm{ml})$. Liver biopsy showed normal architecture with severe iron deposition (grade IV). Treatment included transfusion of six units of blood, parenteral $\mathrm{B}_{12}$, and folic acid.

Three of the patients' four children and six grandchildren had thalassaemia minor with microcytosis and raised $\mathrm{HbA}_{2}$.

On his second admission in November 1976 he presented with continuous sharp right upper quadrant pain for the previous month. He weighed $42 \mathrm{~kg}$ and was icteric. The liver had enlarged into the right lower quadrant and was hard, knobbly, and tender. The haemoglobin concentration was $12.6 \mathrm{~g} / \mathrm{dl}$, MCV $61 \mathrm{fl}, \mathrm{MCH} 22 \mathrm{pg}$, and $\mathrm{MCHC} 34 \mathrm{~g} / \mathrm{dl}(34 \%)$. The serum iron concentration was $19 \mu \mathrm{mol} / \mathrm{l}(106 \mu \mathrm{g} / 100 \mathrm{ml})$, folate $5.4 \mu \mathrm{g} / \mathrm{l}$, and $\mathrm{B}_{12}$ $1320 \mathrm{ng} / \mathrm{l}$. The ferritin concentration was very high at $3593 \mu \mathrm{g} / \mathrm{l}$. The concentration of total bilirubin was $40 \mu \mathrm{mol} / 1(2.3 \mathrm{mg} / 100 \mathrm{ml})$, direct bilirubin $19 \mu \mathrm{mol} / 1$, aspartate transaminase $69 \mathrm{U} / \mathrm{l}$, and alkaline phosphatase $271 \mathrm{U} / 1$. The prothrombin ratio was 1.2 . Hepatitis $B$ antigen was not detected. Alpha-fetoprotein test was positive. Liver scan showed multiple filling defects. Liver biopsy showed both severe iron overload (grade IV) in Küpffer and parenchymal cells, without cirrhosis and hepatocellular carcinoma. The liver iron concentration was $9.83 \mu \mathrm{mol}(550 \mu \mathrm{g}) / 100 \mathrm{mg}$ dry weight (mean normal liver iron $1.4 \mu \mathrm{mol}(78 \mu \mathrm{g}) / 100 \mathrm{mg}$ ) and hepatoma iron $0.9 \mu \mathrm{mol}(50 \mu \mathrm{g}) / 100 \mathrm{mg}$. The patient died with bronchopneumonia three weeks later.

At necropsy the liver weighed $3050 \mathrm{~g}$; the parenchyma was largely replaced by nodules of tumour up to $15 \mathrm{~cm}$ diameter, some of which were necrotic. There was a dramatic blue coloration of parenchyma with potassium ferrocyanide. Microscopy confirmed the biopsy findings. Hepatoma had invaded the hepatic vein and become deposited in lung parenchyma. Tumour emboli were found in the pulmonary artery and left ventricular wall. Large amounts of iron were present in the pancreas, spleen, and marrow. The bone marrow was widened and contained red marrow throughout its length.

\section{Discussion}

Excessive iron storage has rarely been described in thalassaemia minor. Williams and Siemsen ${ }^{1}$ reported a patient with thalassaemia minor who developed haemochromatosis in the absence of any exogenous iron, as occured in the present case. Inappropriate absorption of iron has not been shown in thalassaemia minor ${ }^{3}$ and a study of iron metabolism of the descendants of the present case may help to define the aetiology of the overload.

Hepatoma is rare in iron overload secondary to chronic anaemia. ${ }^{4}$ Barry et $a l^{5}$ reported a patient with hereditary spherocytosis who had iron overload without cirrhosis and developed a hepatoma. The present case is unique because of the development of iron overload without exogenous iron or transfusions; the absence of fibrosis in a heavily iron-loaded liver; and the association between thalassaemia minor, iron overload, and hepatoma.

We thank Dr A L Turnbull for his advice, Dr G Laird for permission to report his patient, Dr D Pollock and Dr A Casswell for their help, and Miss Myra Barnett of St Bartholomew's Hospital for measuring the ferritin and liver iron concentrations.

1 Williams, C E, and Siemsen, A W, Archives of Internal Medicine, 1968, 121, 356.

${ }^{2}$ Chan, C H, Medical Clinics of North America, 1975, 59, 989.

Weatherall, D J, and Clegg, J B, The Thalassaemia Syndromes, p 111. Oxford, Blackwell, 1972.

4 Steinberg, P G, Canale, V C, and Miller, D R, American fournal of Medicine, 1976, 60, 1032

${ }^{5}$ Barry, M, et al, Lancet, 1968, 2, 481.

(Accepted 25 October 1977)

Division of Medicine and Morbid Anatomy, The London Hospital, London E1

P S PARFREY, BSC, MRCP, senior house officer, general medicine MARIAN SQUIER, BSC, MRCP, registrar, morbid anatomy 